らず，発錆試験結果とついて，少くとも Barnum 等の 説と同样によく説明できるととを示した。

交献

(1) Pilz and Farley : I.E. C. 38, 601, (1946)

(2) Barnum, Larsen and Warchter : Corrosion 4, 423 (1948)

(3) Harkins : The phys. Chem. of surface films
(1952)

(4) Harkins and Humphery : J. Am. Chem. Soc. 38, 236 (1916)

（5）桜井, 馬場, 小曾: 油脂協 3, 210 (1954)

(6) 浅原, 後藤：金表技 6, 138 (1955)

(7) Schwoegler and Berman : Lub. Eng. 11, 381 (1955)

\title{
鉄鋼に対する各種防錆処理法の比較について
}

\author{
小川喜代 - * ・高見沢太 助 ${ }^{*}$
}

\section{Comparative Test of Many Anticorrosive Method for Iron-Steel}

\section{Kiyokazu OGAWA and Taisuke TAKAMISAWA}

We tried comparative test of many anticorrosive methods for iron and steel by salt spraying and wheathering, and found that, in the case of non-painting, the iron and steel which were treated by "Zinc plating- chromate treating-oxy dizing" method was superior and that in the case of painting, "Zinc plating-phosphate treating" method, "Zinc plating-chromate treating" method, and "Zinc plating" were nearly as good as "Zinc plating-chromate treating-oxydizing" method.

\section{I 緒䡒}

彷来鉄鋼の防錆処理方法には種々の方沠が行われてい るが，本論では一般と使用される方沠についてその耐食 性を比較検討してみた。実験は主として塩水噴霧試験に よって行ったが, 大気中に打ける懪露試験も同時に行っ た。な抬とれらの結果は肉眼またはカラー写真によって 比較検傠を行ったるのである。

\section{II 実 験 方 法}

\section{A. 塩水噴霧試験}

塩水噴霧試験に関しては1954年 ASTM で定めた方法 があり, これによると食塩水濃度を $5 \%$ \%定めているが 理論的な深い意味はない。ここと扮いては食塩水濃度を $20 \%$ と $50^{\circ} \mathrm{C}\left( \pm 3^{\circ} \mathrm{C}\right)$ の下に実験を行った。その理由 は予借実験の結果によると噴霧試験の効果が食塩水濃度 の偏差よりも, 温度の影響が大であるととを認め得たか らである。

実験装置の概要を第 1 図に示した。すなわち各種防銄 処理を施した試片はいずれる同一条件の下に耐食試験を 行い,その発錆過程ならびそ結果の吟味を行ったもので ある。

実験に用いた試料片は $10 \mathrm{~mm} \times 50 \mathrm{~mm} \times 1 \mathrm{~mm}$ の大き さであって，0.20\%の炭素鋼を用い，その処理条件の種 類については第 1 表にてれを示す。

\footnotetext{
* 東京都立工業奖励館
}

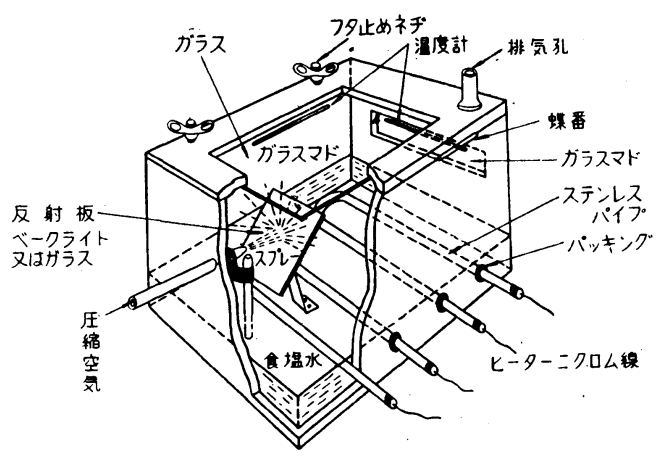

第 1 図䘏水噴霧試験装置

\section{B. 大気中曝露試験}

鉄鋼に防銄処理を施せる製品が種々の雾开気中で発錆 する場合の状況は, 各種の実情に颃ける雾井気中に長時 間さらすことが最も確実の方法であるが，この方法によ ると長期にわたるため, 本論に拈いては主として塩水噴 霧試験法を採用したるのである。しかしわれわれはこの 塩水噴雼と実情にそう試験の比較検討をb併世行うた め, 一般大気中に試片をさらしその变化の状況を肉眼ま たは写真をるって検討した。試片の製作条件怙よび種類 は第2表に示した。

\section{III 結果ならびに考察}

\section{A. 塩水噴雾試験結果}

第2 図は各種防錆処理の試片を $50^{\circ} \mathrm{C}\left( \pm 3^{\circ} \mathrm{C}\right)$, 塩水濃 
䈭 1 表

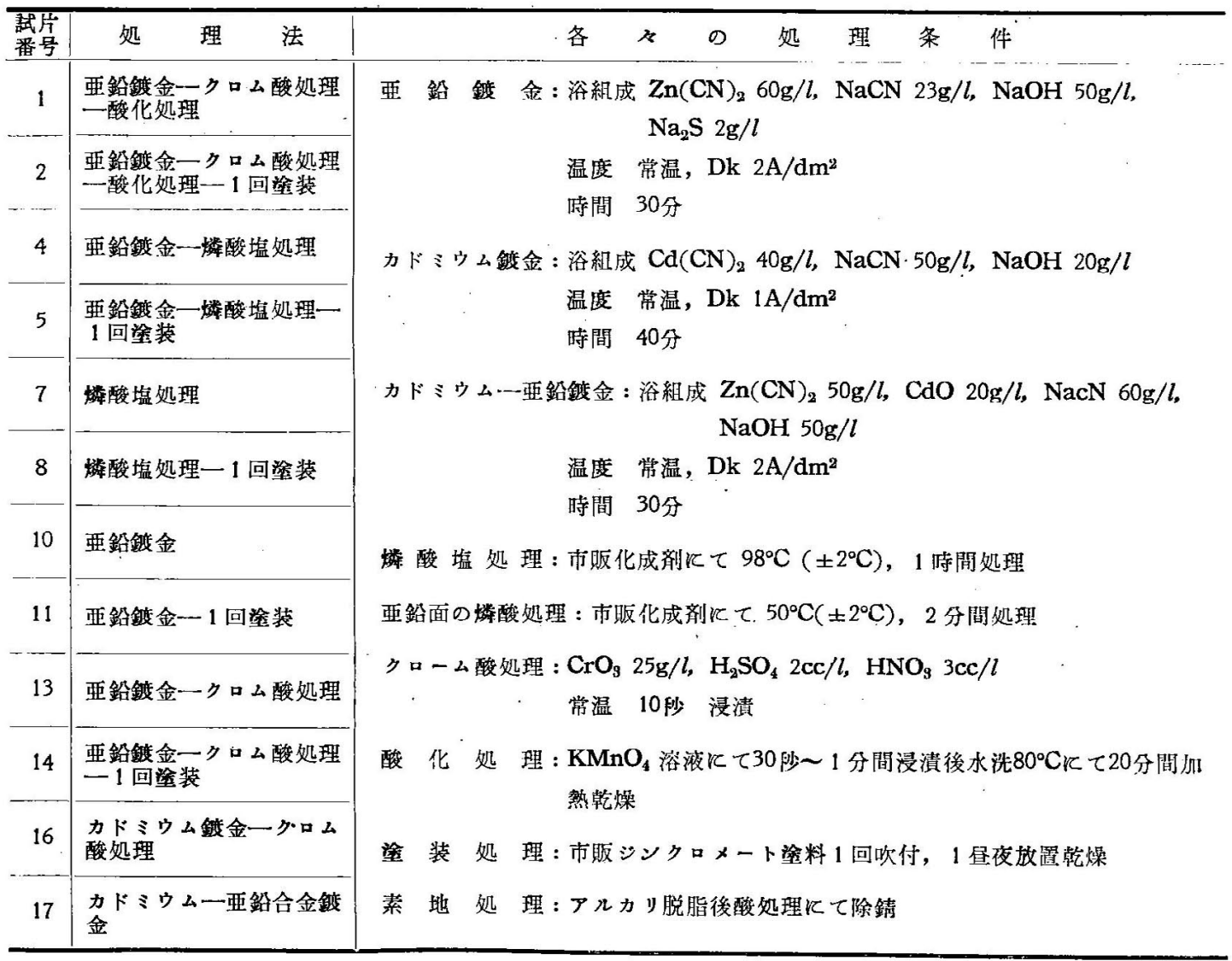

\section{第 2 表}

\begin{tabular}{|c|c|c|}
\hline $\begin{array}{l}\text { 裁片! } \\
\text { 番号! }\end{array}$ & 処 理 法 & 理 \\
\hline 1 & $\begin{array}{l}\text { 垔鉛鍍金一クロム酸 } \\
\text { 柋理 }\end{array}$ & 処理条件は表 1 火同じ \\
\hline 2 & $\begin{array}{l}\text { 亜鉛触金一ク口ム酸 } \\
\text { 処理一酸化処理 }\end{array}$ & 処理条件は表 1 火闹し \\
\hline 3 & $\begin{array}{l}\text { 亜鉛銠金一ク口ム酸 } \\
\text { 処理一酸化処理 }\end{array}$ & $\begin{array}{l}\text { 処理条件は表 } 1 \text { に同じ但し } \\
\text { 乘地サンドーブラスト処理 }\end{array}$ \\
\hline 4 & 垔鉛鍍金一橉酸塩処 & 処理条件は表 1 K同し \\
\hline 5 & 燐酸塩処理 & 上 \\
\hline 6 & 亚鉛鍍金 & 同上 \\
\hline
\end{tabular}

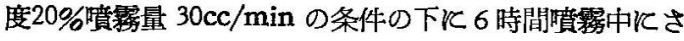
らした後の状態を示したすのて，試料番号に対する肉腿 検討の状況を第 3 表に示した。

\section{B. 大気中懪露試験結果}

第 3 図は大気曝露試験 6 ケ後の状態を示したるのて 試料番昂に対する肉腿榆尉の状況を第 3 表に示した。
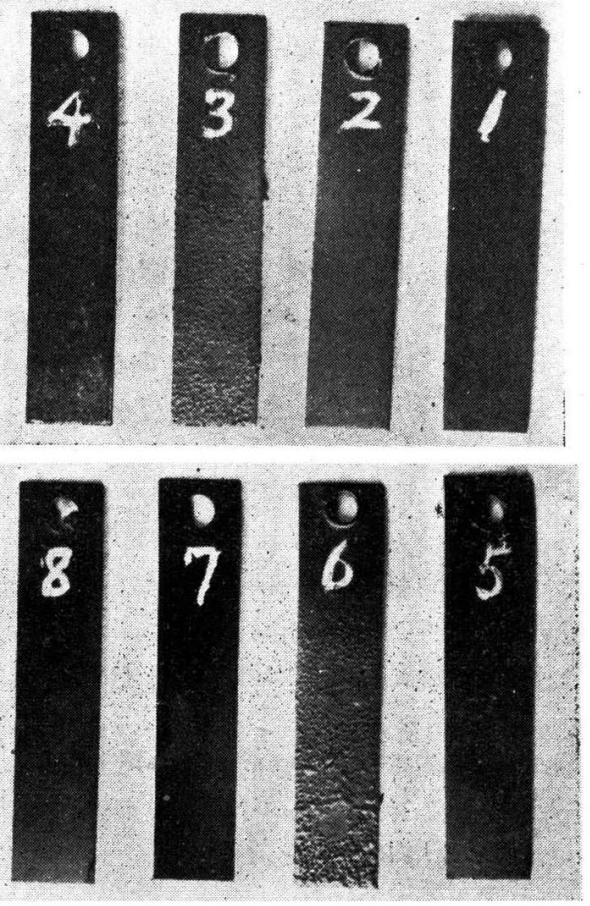

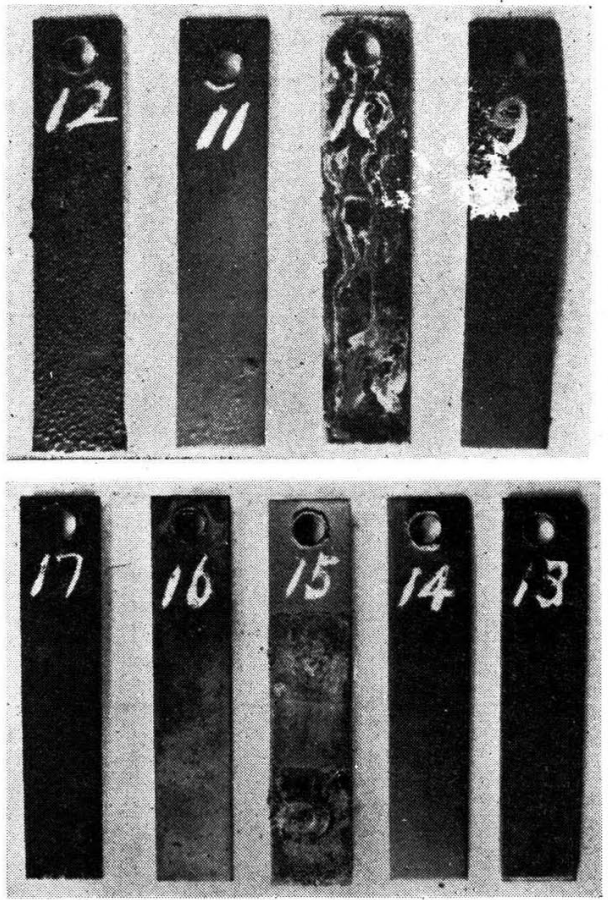

第 2 図

（註）図中試料番号 $3 ， 6 ， 9 ， 12 ， 15$ 亿本実娩と 関係なきため除外す

$$
\text { 事 } 4 \text { 表 }
$$

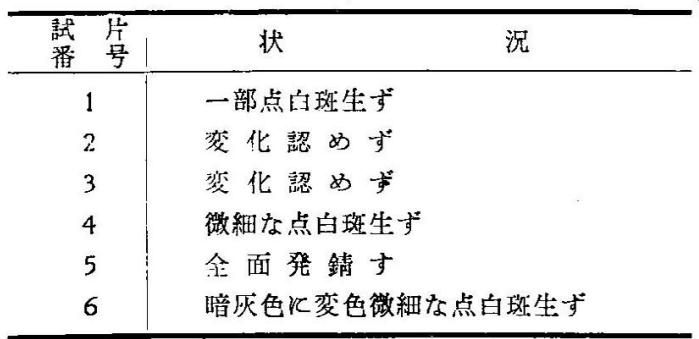

以上実験の結果塩水噴霧試験, 大気曝露試験共に最も 良好の結果を示したものは版鈆鍍金後，クローム酸好理 を施し，さらに酸化处理を施したものであった。これは 西鉛鍍金痛上面のクローム酸処理に上る被膜が更に一種

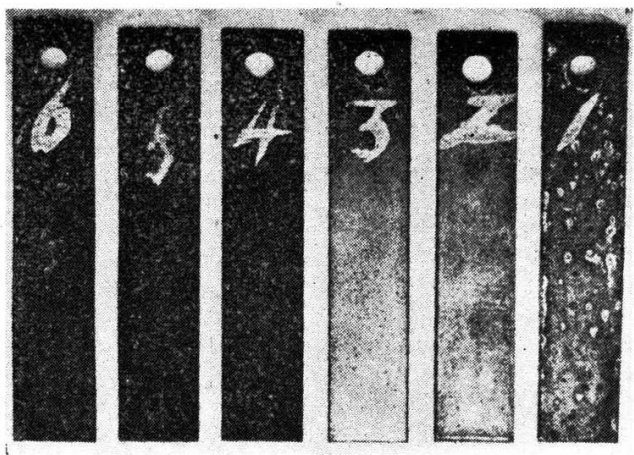

$$
\begin{array}{ccc}
\text { 第 } & 3 & \text { 図 } \\
\text { 第 } & 3 \text {. 是 }
\end{array}
$$

\begin{tabular}{|c|c|c|}
\hline $\begin{array}{ll}\text { 棓 } \\
\text { 番 号 }\end{array}$ & 状 & 沉 \\
\hline 1 & 変 化認 めず & \\
\hline 2 & 変 化認めず & \\
\hline 4 & 一部白斑生寸゙ & \\
\hline 5 & 変 化認めず & \\
\hline 7 & 全面発銷す & \\
\hline 8 & 一 部 浸食一 & \\
\hline 10 & 全面白酷生ず & \\
\hline 11 & 変 化 少 ᄂ & \\
\hline 13 & ․ 部変色す & \\
\hline 14 & 変 化認めず & \\
\hline 16 & 一部白班生ず, 全面変色 & \\
\hline 17 & 全 面 変 色 & \\
\hline
\end{tabular}

の酸化処理により安定化したためその耐蝕性が一首向上 したものと思考される。な打防錆处理の後一回澄装せる 場合は㙁水噴霧試験ては陚料番号 2，5，14が良好の結 果を示し，11がこ机次ぎさらに8がこの次ぎとなる脽 序を示した。な㙁水試駼結果の写真中(7)は比較的变化 がないよう見えるがこれは全面的に赫発生しているる ので黒白写真では，はっきり見党ない。写真(17)《全面変 色しているるのである。また大気中懪露試験結果の写真 (5)は全面発錆のため本军真では，判然と認められない。 (31. 8.10. 受理)

\section{Al および Al 合金上のメッキの耐食性について（第 1 報） Salt Spray による防食效果}

岸松平”。山口春千代*

On the Corrosion-Resistance of the 1'lated Al and Al-Alloys (I) - On the Salt Spray Resistance--

\section{Matsuhei KISHI and Haruchiyo YAMAGUCHI}

The experiment on the salt spray resistance was carried out with the Al and Al-alloy casting, on which $\mathrm{Cu}, \mathrm{Ni}$ and $\mathrm{Cr}$ are plated by single or multiple plating. 
䈭 1 表

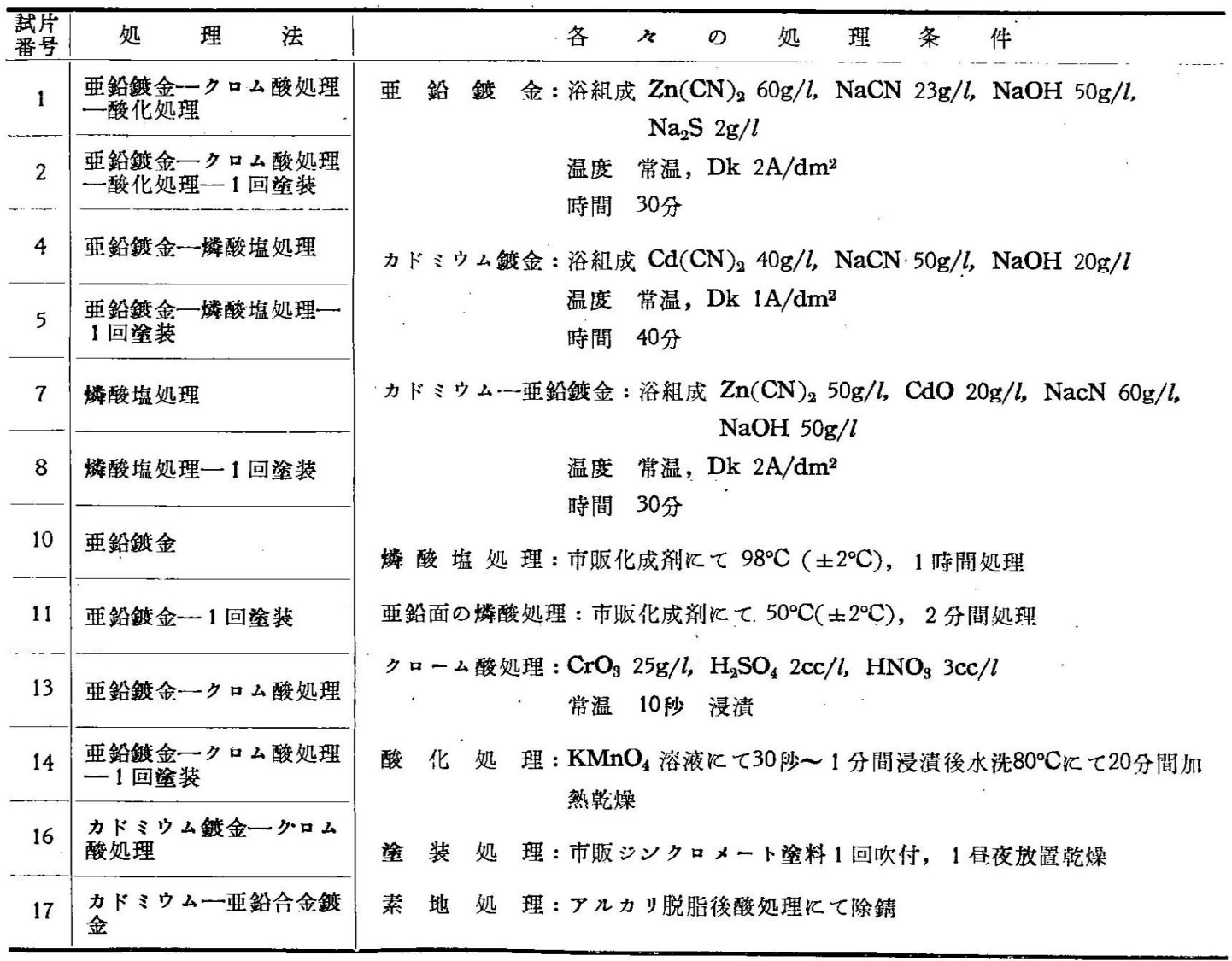

\section{第 2 表}

\begin{tabular}{|c|c|c|}
\hline $\begin{array}{l}\text { 裁片! } \\
\text { 番号! }\end{array}$ & 処 理 法 & 理 \\
\hline 1 & $\begin{array}{l}\text { 垔鉛鍍金一クロム酸 } \\
\text { 柋理 }\end{array}$ & 処理条件は表 1 火同じ \\
\hline 2 & $\begin{array}{l}\text { 亜鉛触金一ク口ム酸 } \\
\text { 処理一酸化処理 }\end{array}$ & 処理条件は表 1 火闹し \\
\hline 3 & $\begin{array}{l}\text { 亜鉛銠金一ク口ム酸 } \\
\text { 処理一酸化処理 }\end{array}$ & $\begin{array}{l}\text { 処理条件は表 } 1 \text { に同じ但し } \\
\text { 乘地サンドーブラスト処理 }\end{array}$ \\
\hline 4 & 垔鉛鍍金一橉酸塩処 & 処理条件は表 1 K同し \\
\hline 5 & 燐酸塩処理 & 上 \\
\hline 6 & 亚鉛鍍金 & 同上 \\
\hline
\end{tabular}

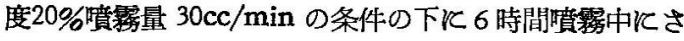
らした後の状態を示したすのて，試料番号に対する肉腿 検討の状況を第 3 表に示した。

\section{B. 大気中懪露試験結果}

第 3 図は大気曝露試験 6 ケ後の状態を示したるのて 試料番昂に対する肉腿榆尉の状況を第 3 表に示した。
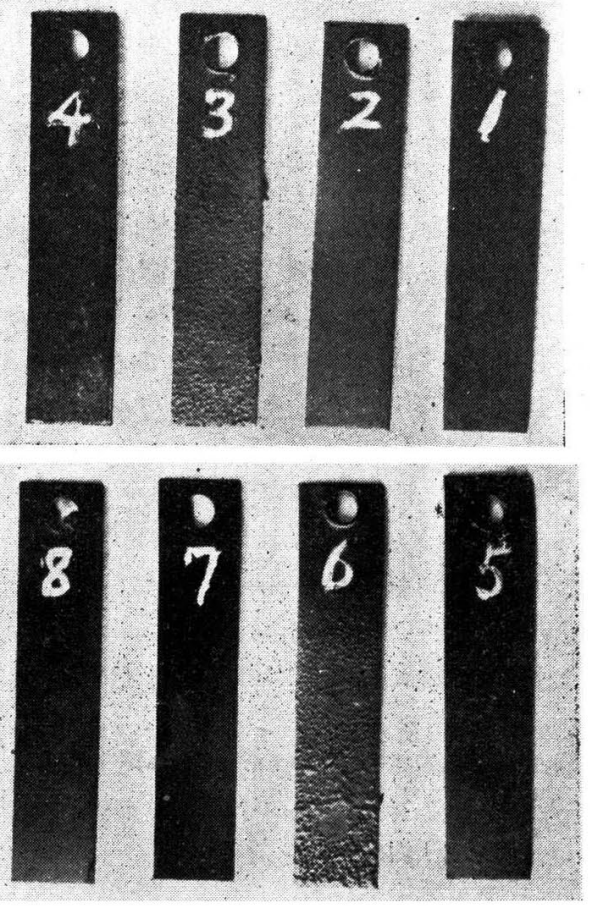

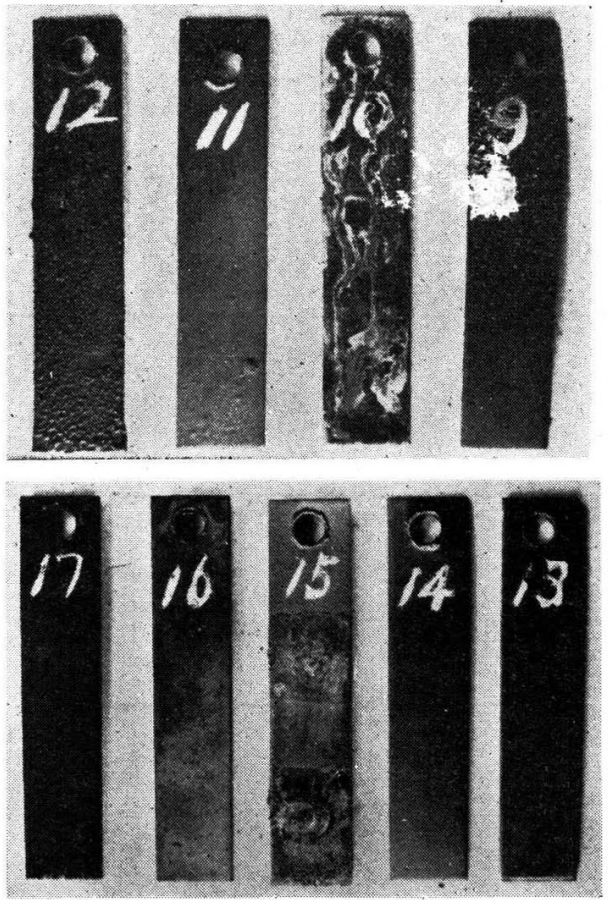

第 2 図

（註）図中試料番号 $3 ， 6 ， 9 ， 12 ， 15$ 亿本実娩と 関係なきため除外す

$$
\text { 事 } 4 \text { 表 }
$$

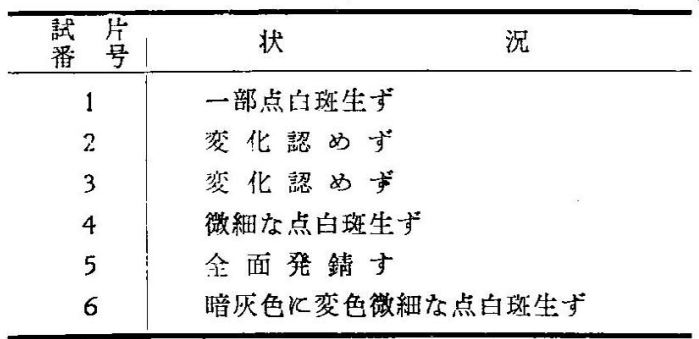

以上実験の結果塩水噴霧試験, 大気曝露試験共に最も 良好の結果を示したものは版鈆鍍金後，クローム酸好理 を施し，さらに酸化处理を施したものであった。これは 西鉛鍍金痛上面のクローム酸処理に上る被膜が更に一種

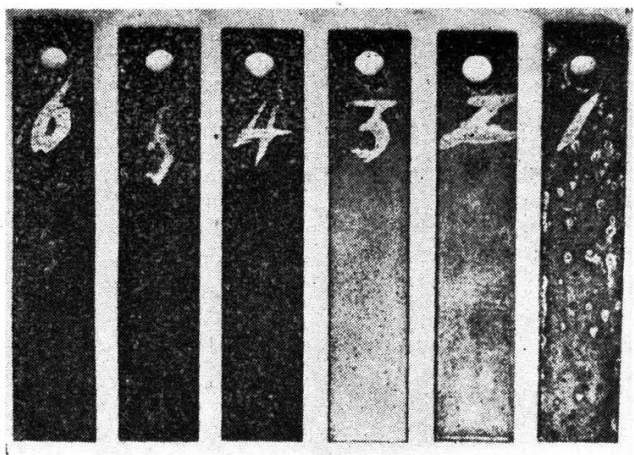

$$
\begin{array}{ccc}
\text { 第 } & 3 & \text { 図 } \\
\text { 第 } & 3 \text {. 是 }
\end{array}
$$

\begin{tabular}{|c|c|c|}
\hline $\begin{array}{ll}\text { 棓 } \\
\text { 番 号 }\end{array}$ & 状 & 沉 \\
\hline 1 & 変 化認 めず & \\
\hline 2 & 変 化認めず & \\
\hline 4 & 一部白斑生寸゙ & \\
\hline 5 & 変 化認めず & \\
\hline 7 & 全面発銷す & \\
\hline 8 & 一 部 浸食一 & \\
\hline 10 & 全面白酷生ず & \\
\hline 11 & 変 化 少 ᄂ & \\
\hline 13 & ․ 部変色す & \\
\hline 14 & 変 化認めず & \\
\hline 16 & 一部白班生ず, 全面変色 & \\
\hline 17 & 全 面 変 色 & \\
\hline
\end{tabular}

の酸化処理により安定化したためその耐蝕性が一首向上 したものと思考される。な打防錆处理の後一回澄装せる 場合は㙁水噴霧試験ては陚料番号 2，5，14が良好の結 果を示し，11がこ机次ぎさらに8がこの次ぎとなる脽 序を示した。な㙁水試駼結果の写真中(7)は比較的变化 がないよう見えるがこれは全面的に赫発生しているる ので黒白写真では，はっきり見党ない。写真(17)《全面変 色しているるのである。また大気中懪露試験結果の写真 (5)は全面発錆のため本军真では，判然と認められない。 (31. 8.10. 受理)

\section{Al および Al 合金上のメッキの耐食性について（第 1 報） Salt Spray による防食效果}

岸松平”。山口春千代*

On the Corrosion-Resistance of the 1'lated Al and Al-Alloys (I) - On the Salt Spray Resistance--

\section{Matsuhei KISHI and Haruchiyo YAMAGUCHI}

The experiment on the salt spray resistance was carried out with the Al and Al-alloy casting, on which $\mathrm{Cu}, \mathrm{Ni}$ and $\mathrm{Cr}$ are plated by single or multiple plating. 